\title{
TIPOLOGI PELAKSANAAN KEWAJIBAN NAFKAH LAHIR SUAMI YANG BERSTATUS NARAPIDANA PERSPEKTIF HUKUM ISLAM (Studi Analisis Interpretasi Teori Qira'ah Mubadalah)
}

\author{
Yulmitra Handayani \\ Mahasiswa Magister Ilmu Syariah Fakultas Syariah dan Hukum \\ Universitas Islam Negeri Sunan Kalijaga Yogyakarta \\ e-mail: yulmitrahandayani14@gmail.com

\begin{tabular}{|l|l|l|}
\hline Diterima: 16-01--2020 & Direvisi: 11-05-2020 & Dipublish: 29-06-2020 \\
\hline
\end{tabular} \\ Abstract: Obligations of conjugal need by a busband, also with the issue of responsibility and the busband's \\ condition to provided. As a prisoner makes a polemic to be provided obligation of the husband. The \\ loss of independence and restrictions on movement cant liability, for physically and mentally. Through \\ this research there are can be discussed; first, how to implement the obligations of a prisoner's \\ husband's conjugal need, and how to understand of living according to Islamic law views this crucial \\ issue. The aim to find the burden of conjugal need status the implication by a husband, which becomes \\ constrained and then as a prisoner. This study was analyzed using a sociological-empirical approach. \\ The results obtained from this study, there are three typologies in the implementation of livelihood \\ obligations of husbands who are prisoners in Rutan Batusangkar; first, implemented with the business \\ going on, and producing. The second is not implemented, the provision of income is inadequate, and the \\ third is not carried out, the opposite is the case, the wife always spends her husband during the \\ criminal period. The view of Islamic law in this case doesnt contradictions, although other side liability \\ for the husband must be fulfilled. Islam seen this with two legal standing, the first is the obligation to \\ maintain a living on the typology of implementation. Second, conjugal need obligations fall and become \\ debt to the typology of the implementation of less and not implemented.
}

Kata kunci: nafkah lahir, tahanan, hukum Islam, qira'ah mubadalah.

\section{PENDAHULUAN}

Narapidana dalam redaksi Undangundang Nomor 12 Tahun 1995 tentang "pemasyarakatan" pasal 1 angka 7 adalah terpidana yang menjalani pidana hilang kemerdekaan di lapas, hilangnya kemerdekaan diartikan sebagai pembatasan gerak-gerik dari terpidana dalam melakukan aktivitas sebelumnya, sebagaimana tujuan dari penerapan pemidanaan yakni, upaya pemberian balasan setimpal (retributif justice), penyadaran terpidana untuk menjadi lebih baik (reformatif justice) dan pemulihan masyarakat dan korban menjadi aman dan damai kembali (restoratif justice). (Kania, 2014: 25) Pembatasan gerak-gerik dari terpidana dalam melakukan aktivitas sebagaimana mestinya berdampak pada sisi kehidupan lainnya, sebagai seorang yang berstatus suami misalnya. Suami yang memiliki hak dan kewajiban terhadap isteri dan anaknya sebagaimana diatur di dalam Undang-undang Nomor 1 Tahun 1974 Tentang Perkawinan (selanjutnya disebut Undang-Undang Perkawinan) dan Intruksi 
14

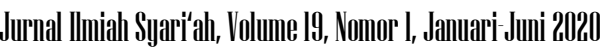

Presiden Republik Indonesia Nomor 1 Tahun 1991 tentang Kompilasi Hukum Islam (selanjutnya disebut KHI) menjadi terkendala.

Hakikatnya, segala aturan mengenai hak dan kewajiban suami isteri dalam rumah tangga tidak lain bertujuan agar pasangan suami isteri bisa saling mengerti, memahami kodrati sebagai insan yang telah berpasangan, mengikat janji yang kekal lagi sakral (mitsaqan ghalidza). Itu artinya, pemenuhan hak dan kewajiban antara masing-masing pihak adalah suatu keharusan yang dipenuhi.

Menelisik kembali mengenai status narapidana yang disandang oleh suami tentu akan berdampak pada sisi kehidupan rumah tangganya, yang paling sensitif mengenai pemenuhan kewajiban nafkah lahir dan batin sebagaimana di ulas diawal. Hal ini tentu tidak dapat dikesampingkan hanya dengan dasar "apa hendak dikata" yang menandakan penerimaan secara tidak terima (klise) pada keadaan yang terjadi.

Sebagai pengantar berdasarkan informasi dan data yang penulis peroleh melalui situs resmi dari SPD (Sistem Database Pemasyarakatan) yang dipublikasikan oleh Direktorat Jendral Pemasyarakatan (Ditjen PAS) Kementrian Hukum dan Hak Asasi Manusia dari data yang disuplai langsung oleh Unit Pelaksana Teknis di lapangan, dan setelah penulis konfirmasi terkait keakuratan dan audit terkini mengenai jumlah warga binaan di Rumah Tahanan Negara Klas II B Batusangkar (selanjutnya disebut Rutan Batusangkar) ini diperoleh data sebagai berikut:
Tabel I.1

Data Warga Binaan

Rumah Tahanan Negara Klas II B Batusangkar Data audit 17 Oktober 2017

\begin{tabular}{|c|l|c|c|}
\hline NO & JENIS KEJAHATAN & NAPI & T \\
\hline 1 & Perlindungan Anak & 27 & 6 \\
\hline 2 & Pencurian & 13 & 5 \\
\hline 3 & Narkotika/Ganja/Ekstasi & 18 & 21 \\
\hline 4 & Perjudian & 3 & 0 \\
\hline 5 & Asusila & 1 & 0 \\
\hline 6 & Penganiayaan & 2 & 0 \\
\hline 7 & Penipuan & 7 & 0 \\
\hline 8 & Laka Lantas & 4 & 0 \\
\hline 9 & Korupsi & 2 & 0 \\
\hline 10 & Penadahan & 1 & 1 \\
\hline \multicolumn{2}{|c|}{ Jumlah } & $\mathbf{7 8}$ & $\mathbf{3 3}$ \\
\hline
\end{tabular}

Sumber Data: Situs resmi SPD (Sistem Database Pemasyarakatan) yang dipublikasikan oleh Direktorat Jendral Pemasyarakatan (Ditjen PAS) Kementrian Hukum \& HAM dari data yang disuplai langsung oleh Unit Pelaksana Teknis di lapangan dan Penulis konfirmasi secara langsung pada 17 Oktober 2017 di Rumah Tahanan Negara Klas II B Batusangkar. (HAM 2017)

Para narapidana di Rutan Batusangkar ini memiliki beragam pekerjaan yang mereka tekuni sebelum mendekam di dalam penjara, seperti: pedagang, Pegawai Negeri Sipil (PNS) bahkan notabene dari narapidana tersebut tidak memiliki pekerjaan sebelumnya dan atau serabutan. (Betti Noon, 2018)

Berdasarkan data yang penulis peroleh bahwa $46 \%$ dari jumlah populasi warga binaan telah berkeluarga, $24 \%$ belum berkeluarga dan 30\% pernah berkeluarga, dengan jumlah audit terakhir:

Tabel I.2

Status Perkawinan Warga Binaan Rumah Tahanan Negara Klas II B Batusangkar

\begin{tabular}{|c|l|l|}
\hline NO & \multicolumn{1}{|c|}{ STATUS } & \multicolumn{1}{|c|}{ JUMLAH } \\
\hline 1 & Kawin & 51 Orang \\
\hline 2 & Belum Kawin & 27 Orang \\
\hline 3 & Duda/Janda & 33 Orang \\
\hline \multicolumn{2}{|c|}{ Jumlah Keseluruhan } & 111 Orang \\
\hline
\end{tabular}

Sumber Data: (Rini, 2018) 
Keadaan warga binaan yang telah berkeluarga dan sebagaimana ulasan penulis diawal, menjadi sebuah permasalahan yang mana ketika para suami menyandang status sebagai narapidana maka serta merta ada beban dan tugas baru yang harus ditanggung oleh isteri, yaitu bagaimana mempertahankan keutuhan rumah tangganya dalam keadaan suami yang sedang menjalani masa pemidanaan, sekaligus sebagai tulang punggung yang harus memikirkan kelangsungan hidup keluarganya terutama persoalan nafkah. Sementara secara normative nafkah merupakan kewajiban yang harus ia tunaikan selaku kepala keluarga -suami.

Beruntungnya apabila isteri dari suami yang berstatus sebagai narapidana merupakan wanita karir dalam artian memiliki penghasilan dan tidak terlalu mempersoalkan nafkah bagi dirinya, namun bagi pasangan yang kehidupan ekonominya menengah ke bawah maka keadaan seperti ini akan memaksa mereka untuk bekerja guna mencukupi kebutuhan sehari-hari, dan tidak dapat dinafikan hal tersebut (status narapidana suami) terkadang dapat dijadikan salah satu alasan bagi mereka untuk mengakhiri perkawinannya sebagaimana yang diatur oleh PP No 9/1975 Pasal 19 huruf (c) menyatakan perceraian dapat terjadi karena alasan salah satu pihak mendapat hukuman penjara 5 (lima) tahun atau hukuman yang paling berat setelah perkawinan berlangsung. Artinya, mistaqan ghalidza dalam perkawinan tidak lagi menjadi sesuatu yang sakral, melainkan sangat profan.

Berangkat dari potret fenomena tersebut setidaknya terdapat dua pokok permasalahan yaitu, 1) bagaimana bentuk pelaksanaan kewajiban nafkah lahir suami yang berstatus narapidana? 2) bagaimana hukum Islam memandang persoalan tersebut?

\section{METODE PENELITIAN}

Penentuan metode penelitian adalah langkah vital untuk mengantarkan bagaimana penelitian ini bekerja dengan optimal dan mencapai maksud secara terarah dan berimbang. Setidaknya untuk menjawab pertanyaan tersebut, penelitian ini menggunakan pendekatan Empiris, dengan kerangka konseptual mashlahah (hukum Islam) dan mengelaborasi tafsir kesalingan (mubadalah) sebagai sebuah teori analisa. Penelitian ini merupakan penelitian lapangan (field research) yang memotret secara mendalam bentuk pelaksanaan kewajiban nafkah lahir suami narapidana terhadap keluarga yang dijadikan sebagai sumber data primer kajian ini, dan didukung oleh literaturliteratur lain sebagai sumber data sekunder.

Guna menemukan orisinalitas penelitian ini, peneliti melakukan penelusuran pada penelitian-penelitian terkait yang berbicara tentang kewajiban nafkah, relasi keluarga "bermasalah" dan narapidana. Dari hasil pelacakan, peneliti menemukan beberapa penelitian terkait topik riset ini meskipun secara umum, karena riset yang langsung secara khusus menyinggung topik penelitian ini belum terlalu banyak disinggung atau bahkan belum dilakukan. Sekiranya pun ada, kajian tersebut menggunakan studi keilmuan yang berbeda. Sebagaimana Esi Susilawati, dalam skripsinya Pelaksanaan 
Hak dan Kewajiban Suami Isteri (Studi Kasus di Nagari Pariangan Kabupaten Tanah Datar)". Penelitian ini mempersoalkan tentang bentuk-bentuk pelaksanaan hak dan kewajiban dan apa saja permasalahan dalam pelaksanaan dalam pelaksanaan hak dan kewajiban suami isteri di Nagari Pariangan Kabupaten Tanah Datar dengan problematika suami tidak memiliki pekerjaan dan isteri yang menafkahi keluarganya.

Penelitian senada juga dilakukan oleh oleh Mardha Tillahi, dengan berfokus kepada Dampak bagi Rumah Tangga isteri yang berprofesi sebagai TKI (Studi Kasus di Kecamatan Lima Kaum)". Penilitian ini mempersoalkan apa saja dampak bagi rumah tangga yang ditimbulkan terkait pada pelaksanaan hak dan kewajiban terhadap isteri yang berprofesi sebagai TKI. Kemudian, riset Muhammad Fathihnuddin tentang "Aplikasi Kewajiban Suami Terhadap Isteri dikalangan Jamaah Tabligh (Tinjauan atas penerapan hak dan kewajiban suami isteri)". Yulia Ningsih dengan skripsinya berjudul "Eksistensi Kewajiban Nafkah Terhadap Isteri Bekerja (Studi Komparasi Hukum Islam dengan Pendekatan Pengusurataan Gender)" yang mana obyek penelitian ini adalah yang berisikan pelaksanaan kewajiban nafkah suami terhadap isterinya yang bekerja.

Lukman Hakim, yang menulis skripsi dengan judul "Pemenuhan Nafkah Batin Isteri yang Terpidana dan Implikasinya Bagi Keharmonisan Keluarga (Studi Kasus Lapas Wanita, Sukun, Malang)", obyek penelitian ini adalah nafkah bathin yang harus dipenuhi oleh isteri yang tengah menyandang status sebagai narapidana.

Sedangkan penulis meneliti tentang bentuk-bentuk pelaksanaan kewajiban nafkah lahir bagi suami yang berstatus sebagai narapidana, dan tinjauan hukum Islam terhadap kewajiban nafkah lahir suami yang berstatus narapidana tersebut.

\section{NAFKAH: KEWAJIBAN SUAMI ATAS ISTERINYA}

Menjadi akibat hukum baru yang harus ditunaikan ketika telah menyandang status dan peran sebagai seorang suami, adanya hak-hak sekaligus kewajiban baru yang mulanya tidak diberatkan, diantaranya menunaikan nafkah. (Kisyik, 1995: 128)

Secara normative, nafkah diartikan sebagai tanggung jawab antara seorang pemilik kepada sesuatu yang dimilikinya, juga tertuang dalam QS. Al Baqarah [2]: 233 lalu dipertegas oleh QS. ath-Thalaq [65]: 6 yang menyatakan bahwa nafkah adalah kewajiban yang harus ditunaikan berupa; lahir dan batin.

Ulama sepakat tentang memberikan definisi nafkah sebagai biaya yang meliputi kebutuhan pokok, sekunder dan tersier dalam rumah tangganya, yang dimulai semenjak suami telah berjima' dengan istrinya. Salah satunya Imam Syafi'i yang memandang bahwa pernikahan telah mewajibkan seorang suami atas nafkah terhadap isterinya, meski isteri kafir sekalipun, dengan syarat pernikahan yang sah, tetapi jika fasid, maka sebaliknya suami berhak meminta kembali apabila nafkah telah ditunaikan (Mustofa, 2019: 60). Tidak sampai disana, ulama juga menyertakan pandangannya terhadap pertimbangan atas kesanggupan 
pemberi nafkah dalam menunaikannya, sebagaimana dasar hukum nafkah di atas.

Menyoal kadar kesanggupan pemberian nafkah oleh suami, maka berbicara sebab kewajiban pemberian nafkah itu sendiri, sebagaimana kausalitas lahirnya kewajiban nafkah dipengaruhi oleh; pertama, zaujiyyah yang diartikan sebagai akibat ikatan pernikahan yang sah. Kedua, qarabah yang dimaknai dengan adanya hubungan kekerabatan. Silang pendapat terhadap term ini hadir dari kalangan Malikiyah yang menilai qarabah yang wajib hanya kepada orangtua dan anak. Syafi'iyyah menambahkan hubungan cucu dan kakek selain orang tua dan anak, kemudian Hanafiyah menilai qarabah kepada dimensi mahram tanpa batasan ushul; furu'sehingga sangat memungkinkan jalur kesamping. Lain halnya dengan Habailah yang memahami qarabah kedalam hubungan mawaris, yang berada pada jalur nasab. (Subaidi, 2014: 159)

Dimensi yang mempengaruhi kewajiban nafkah selanjutnya adalah milk. Dimensi ini diartikan sebagai sebab kepemilikan atas sesuatu. Hari ini, dimensi ini dipahami sebagai hubungan kepemilikan berorientasi tanggungan. Seperti contoh; jasa asisten rumah tangga, pemeliharaan hewan peliharaan, dan sejenisnya. (Subaidi, 2014: 159) Dimensi ini juga dapat dikatakan sebagai kewajiban atas kebutuhan tersier yang tidak terlalu menuntut untuk ditunaikan.

Term atau dimensi kausalitas kewajiban nafkah di atas dipahami bahwa sebab-sebab nafkah pada prinsipnya berada pada pundak laki-laki. Suami terhadap isterinya, pun ketika telah memiliki anak, meliputi anaknya. (Subaidi, 2014: 160)

\section{DISKURSUS KADAR NAFKAH}

Menyoal definisi nafkah sebagaimana di atas telah selesai diperbincangkan, persoalannya kemudian adalah kadar pemberian nafkah yang masih menyisakan silang pendapat ditengah pandangan jumhur. Kalangan Malikiyah berpandangan ukuran nafkah sebenarnya tidak diatur secara kuantitaif oleh syara', yang artinya dikembalikan kepada keadaan suami. Pendapat itu diikuti oleh Imam Abu Hanifah. Kemudian Imam Syafii juga menetapkan bahwa nafkah isteri setiap hari sebanyak dua mud yang dikonfrensikan hari ini 1.400 Gram beras apabila ketentuan suami mampu. Bila kemampuan suami terkategori sedang, maka kewajibannya hanya pada 1.5 mud, pada kasuistik suami yang tidak mampu hanya membayar 1 mud (1.5 kg beras). Konferensi lain bisa pada status sosial dan kemampuan ekonomi suami. (Hariadi, 2017: 28)

Pemaparan singkat ulama tersebut setidaknya mengambarkan bahwa memang konsep kewajiban nafkah dibebankan sesuai dengan kemampuan suami. QS. At-Thalaq [65]: 6 sebagai dasar nafkah yang dipahami jumhur ulama menyatakan ketidakmampuan suami dalam menunaikan nafkah terhadap isterinya bukan meniscayakan suatu kewajiban yang seharusnya diemban, melainkan memiliki status hukum baru, yakni terhutang yang harus dibayarkan ketika suami telah memiliki kemampuan yang memadai terhadap kadar nafkah 
kehidupan sehari-hari isteri. (Subaidi, 2014: 160)

Sederhananya, bahwa kadar nafkah yang paling ideal dibebankan suami terhadap isteri dan anak sebagaimana konteks ma'ruf yang termaktub dalam alQuran, yaitu melihat kepada kedudukan sosial dan tingkat kemampuan suami. Tidak berlebih-lebihan sehingga terkesan memberatkan suami dan tidak menyedikitkan sehingga terkesan tidak sepenuh hati bertanggungjawab atas isteri. (Bahri, 2015: 397)

\section{POTRET NARAPIDANA DI RUTAN BATUSANGKAR}

Rutan Batusangkar yang terletak di Batusangkar Kabupaten Tanah Datar ini menjadi salah satu cagar budaya dan aset bagi pemerintah daerah karena terbilang pembangunan yang cukup bersejarah, sejak penjajahan Belanda, tahun 1865. Rutan Batusangkar juga instansi pemerintah yang mengedepankan revolusi mental bagi para penyintas tindak kejahatan selingkup tanah datar.

Data terakhir yang diperoleh tahun 2017 terkait data narapidana lengkap dengan status perkawinan dan vonis hukuman yang dijalani informan, sebagai berikut:

Tabel 4.2

Daftar Narapidana/Responden/Informan Penelitian

\begin{tabular}{|c|c|c|c|}
\hline NO & $\begin{array}{l}\text { NA } \\
\text { MA }\end{array}$ & $\begin{array}{l}\text { STATUS } \\
\text { PERKA- } \\
\text { WINAN }\end{array}$ & HUKUMAN \\
\hline I & $\mathrm{RM}$ & Kawin & $\begin{array}{l}\text { Pidana Penjara } 12 \text { (dua belas) } \\
\text { tahun dan denda Rp. } \\
1.000 .000 .000,-\quad \text { (satu milyar } \\
\text { rupiah) subsidair } 6 \text { (enam) } \\
\text { bulan kurungan }\end{array}$ \\
\hline II & MR & Kawin & $\begin{array}{l}\text { Pidana Penjara } 9 \text { (Sembilan) } \\
\text { tahun dan denda Rp. } \\
60.000 .000 \text {,- (Enam Puluh Juta } \\
\text { Rupiah) Subsidair } 6 \text { (Enam) }\end{array}$ \\
\hline
\end{tabular}

\begin{tabular}{|c|c|c|c|}
\hline & & & bulan \\
\hline III & DC & Kawin & $\begin{array}{l}\text { Pidana Penjara } 7 \text { (tujuh) tahun } \\
\text { dan denda Rp. } 1.000 .000 .000, \\
\text { (Satu Milyar Rupiah) } \\
\text { subsidair } 1 \text { (satu ) bulan } \\
\text { pidana penjara }\end{array}$ \\
\hline IV & AN & Kawin & $\begin{array}{l}6 \text { (enam) tahun pidana } \\
\text { penjara dan denda Rp. } \\
60.000 .000,-(\text { Enam Puluh Juta } \\
\text { Rupiah) Subsidair } 2 \text { (dua) } \\
\text { bulan kurungan }\end{array}$ \\
\hline V & BI & Kawin & $\begin{array}{l}\text { Pidana Penjara } 6 \text { (enam) } \\
\text { tahun dan denda Rp. } \\
60.000 .000,- \text { (enam puluh juta } \\
\text { rupiah) subsidair } 2 \text { (dua) } \\
\text { bulan kurungan. }\end{array}$ \\
\hline VI & ZA & Kawin & $\begin{array}{l}\text { Pidana Penjara } 6 \text { (enam) } \\
\text { tahun dan dendaRp } \\
60.000 .000,- \text { (enam puluh juta } \\
\text { rupiah) subsidair } 2 \text { (dua) } \\
\text { bulan kurungan }\end{array}$ \\
\hline VII & IL & Kawin & 5 (lima) Tahun Pidana Penjara \\
\hline VIII & MER & Kawin & $\begin{array}{l}\text { Pidana Penjara } 5 \text { (lima) tahun } \\
\text { ditambah denda Rp } \\
200.000 .000,- \text { (dua ratus juta } \\
\text { rupiah) Subsidair } 6 \text { (enam) } \\
\text { bulan kurungan, Uang } \\
\text { Penganti Rp. 181.186.450, } \\
\text { (Seratus delapan puluh satu } \\
\text { juta seratus delapan puluh } \\
\text { enam ribu empat ratus lima } \\
\text { puluh ribu rupiah). }\end{array}$ \\
\hline IX & DS & Kawin & $\begin{array}{l}\text { Pidana Penjara } 5 \text { (lima) tahun } \\
\text { dan denda Rp. } 1.000 .000 .000, \\
\text { (satu milyar rupiah) subsidair } \\
2 \text { (dua) bulan pidana penjara }\end{array}$ \\
\hline $\mathbf{X}$ & HD & Kawin & $\begin{array}{l}\text { Pidana Penjara } 5 \text { (lima) tahun } \\
\text { dan denda Rp. } 1.000 .000 .000, \\
\text { (satu milyar rupiah) subsidair } \\
3 \text { (tiga) bulan pidana penjara }\end{array}$ \\
\hline XI & YF & Kawin & $\begin{array}{l}\text { Pidana Penjara } 5 \text { (lima) tahun } \\
\text { dan denda Rp. } 1.000 .000 .000, \\
\text { (satu milyar rupiah) subsidair } \\
2 \text { (dua) bulan pidana penjara }\end{array}$ \\
\hline XII & DF & Kawin & $\begin{array}{l}\text { Pidana Penjara } 5 \text { (lima) tahun } \\
\text { dan denda Rp. } 1.000 .000 .000, \\
\text { (satu milyar rupiah) subsidair } \\
2 \text { (dua) bulan pidana penjara }\end{array}$ \\
\hline XIII & FEH & Kawin & $\begin{array}{l}\text { Pidana Penjara } 2 \text { (dua) tahun } \\
6 \text { (enam) bulan }\end{array}$ \\
\hline XIV & $\mathrm{RC}$ & Duda & $\begin{array}{l}\text { Pidana Penjara } 1 \text { (satu) tahun } \\
7 \text { (Tujuh) Bulan }\end{array}$ \\
\hline
\end{tabular}




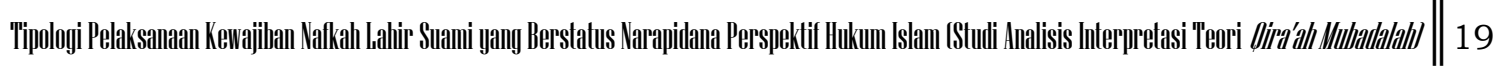

\begin{tabular}{|l|l|l|l|}
\hline XV & RA & Kawin & $\begin{array}{l}\text { Pidana Penjara 1 (satu) tahun } \\
7 \text { (Tujuh) Bulan }\end{array}$ \\
\hline
\end{tabular}

\section{TIPOLOGI PEKAKSANAAN KEWA- JIBAN NAFKAH OLEH SUAMI NARAPIDANA}

Seorang laki-laki yang telah menikah dituntut untuk memenuhi kewajiban terhadap isteri baik secara lahir maupun batin. Khususnya kewajiban suami yang berkaitan dengan nafkah seperti makanan, pakaian, tempat tinggal, biaya rumah tangga, biaya perawatan, dan biaya pengobatan sampai adanya ketetapan yang menetapkan bahwa suami tidak lagi wajib (gugur) menjalankan kewajibannya. Dalam hal ini, seorang suami yang berstatus narapidana, maka mereka memiliki berbagai halangan dalam menafkahi dan mencukupi kebutuhan keluarganya terutama kepada isteri dikarenakan keterbatasan yang dimiliki oleh seorang narapidana yang mana segala gerak geriknya sangat dibatasi atau dengan kata lain mereka kehilangan kemerdekaan yang disebabkan oleh perbuatanya.

Berdasarkan data dan hasil wawancara yang diperoleh, pelaksanaan kewajiban nafkah dari seorang suami yang berstatus narapidana terhadap isteri bersifat relatif. Beberapa penjelasan dari Informan yaitu narapidana di Rutan Batusangkar, Penulis memperoleh informasi bahwa pemberian nafkah terhadap isteri ketika suami berstatus sebagai narapidana sebahagian mampu untuk menjalankan nafkah dan sebahagian yang lain tidak. Berdasarkan hasil wawancara dan setelah dikelompokkan dan dipilah, maka Penulis bisa mengelompokkan pelaksanaan kewajiban nafkah tersebut ke dalam 3 (tiga) kelompok, sebagaimana berikut:

\section{Terlaksana}

Pengelompokkan pelaksanaan kewajiban nafkah oleh suami yang berstatus narapidana dapat dikatakan terlaksana memiliki standarisasi sebagaimana kebiasaan pelaksanaan kewajiban nafkah oleh suami terhadap kebutuhan sehari-hari isteri pada saat suami belum menjalani hukuman maupun tengah menjalani hukuman tetap tercukupi. Salah satu pelaksanaannya adalah dengan suami memberikan wewenang untuk mengelola atau melanjutkan usaha bersama yang ditinggalkan untuk pemenuhan kebutuhan. Sebagaimana yang diungkapkan oleh salah satu narapidana (DC selaku Informan III) mengatakan:

"Saya berdagang sate bersama isteri saya, sebelum berada di sini, dan kini usaha sate tersebut dilanjutkan oleh isteri dan mertua saya di Pincuran Tujuh. Sebelum di sini saya juga mengelola sendiri sawah dan kebun milik kami, dan sekarang juga isteri saya yang melanjutkannya". (Wawancara, 17 Oktober 2017)

Dari keterangan yang diberikan oleh Informan III, hemat Penulis bahwa kewajiban nafkah tetap terlaksana sebagaimana mestinya, hal ini disebabkan oleh Informan III memberikan wewenang kepada isteri untuk melanjutkan usaha bersama mereka yang mana mampu untuk mencukupi kebutuhan hidup sehari-hari isteri. Selain itu, adanya kewenangan lain yang dilimpahkan kepada isteri ialah dengan mengelola harta bersama 
berupa sawah dan kebun yang hasilnya pun mampu mencukupi kebutuhan. Dalam artian, pemenuhan kewajiban nafkah yang diberikan oleh suami kepada isteri memang tidak secara maksimal diberikan seperti pada saat suami belum menjalani hukuman, namun dengan adanya pelimpahan hak untuk melanjutkan usaha yang dikelola bersama menjadikan kewajiban nafkah suami terpenuhi secara tidak langsung. Hak isteri terhadap kewajiban nafkah ketika suami menyandang status narapidana tidak semata membuat isteri merasa keberatan untuk melanjutkan usaha sendiri guna pemenuhan kebutuhan sehari-hari, melainkan hal tersebut menjadikan pelajaran berharga terhadap keluarga mereka untuk mempertahankan keutuhan rumah tangga yang harmonis. Sebagaimana Penulis konfirmasi langsung kepada isteri Informan III (Ibu ND, 33 Tahun) beliau mengatakan: "Usaha ini sebelumnya saya lakoni bersama suami saya, selama suami saya berada didalam, usaha ini saya dan orangtua saya yang melanjutkannya. Hasilnya alhamdulillah, dan terkadang suami saya mendapat kiriman dari orangtuanya ketika mengunjunginya, dan memberikannya sedikit kepada saya dan anak untuk uang belanja Dan alhamdulillah saya bersyukur, meskipun dengan keadaan dia yang seperti itu masih ingat dengan tanggungjawab terhadap kami, padahal saya ikhlas dengan keadaan dia sebagai seorang suami yang tidak memberikan kiriman tersebut kepada kami, karena saya tahu biaya hidup di dalam jauh lebih besar dari pada diluar". (Wawancara, 31 Oktober 2017)

Keadaan pelaksanaan kewajiban nafkah yang hampir serupa dilakukan oleh Informan $\mathrm{V}$, yang mana sebelum mendekam Informan $\mathrm{V}$ memiliki pekerjaan tetap sebagai Pegawai Negeri Sipil (Guru SD) dan mengelola langsung usaha penyewaan musik orgen di kediamannya, oleh sebab perbuatan yang ia lakukan tersebut mengakibatkan status PNSnya dicabut sehingga gaji pun serta merta tidak diperoleh lagi, sehingga keadaan menafkahi secara langsung memang tidak terlaksana sebagaimana mestinya pada saat Informan $\mathrm{V}$ masih memiliki penghasilan tetap sebagai PNS, namun dikarenakan adanya usaha sampingan tersebut, yang kini diambil alih tanggungjawab oleh isteri yang ditinggalkan, sehingga mampu untuk membelanjai kebutuhan hidup seharihari isteri. Sebagaimana keterangan dari Informan $\mathrm{V}$, mengatakan:

"Selain saya mengajar sebagai guru PNS di SDN 27 Dusun Tuo, di rumah saya juga memiliki usaha penyewaan musik orgen yang dulu saya kelola bersama isteri dan adik ipar saya, sekarang dilanjutkan oleh mereka". (Wawancara, tanggal 17 Oktober 2017)

Keadaan serupapun dilakukan oleh para Informan VIII, IX, XI, dan XIII yang dilatarbelakangi oleh pekerjaan yang dilakoni oleh para Informan sebelum menjalani masa pemidanaannya namun dalam bentuk dan jenis profesi yang berbeda, yang mana Informan VIII berprofesi sebagai wali nagari yang memiliki usaha sampingan yakni Toko Sembako, Informan IX memiliki pekerjaan dan pemiliki Perabot dan Furniture di Pekanbaru, kemudian Informan XI memiliki pekerjaan dan usaha pengepul barang bekas, yang kini dikelola oleh isteri dan anak-anak beliau.

Umumnya, para Informan memiliki beberapa pekerjaan serta usaha sampingan yang menghasilkan 
dan kini dilanjutkan oleh isteri dan keluarga yang ditinggalkan. Dalam artian dengan adanya penghasilan yang didapati dari usaha yang ditinggalkan tersebut untuk kebutuhan sehari-hari bagi isteri dirasa bukanlah suatu persoalan.

Penulis berpendapat dalam keadaan seorang suami yang menyandang status sebagai narapidana yang pada saat ini masih memiliki pekerjaan atau usaha yang masih bergerak dan menghasilkan hal itu dapat dikatakan sebagai pemenuhan kewajiban nafkah tetap terlaksana sebagaimana mestinya meskipun pemenuhannya secara tidak langsung.

\section{Kurang Terlaksana}

Pengelompokkan pelaksanaan kewajiban nafkah oleh suami yang berstatus narapidana dikatakan kurang terlaksana sebagaimana mestinya dikarenakan pada saat sebelum suami menjalani masa pidana memiliki pekerjaan dan berpenghasilan, namun selama menjalani masa pemidanaan serta merta membuat suami tidak memiliki penghasilan dan pemenuhan kebutuhan hidup sehari-hari diambil alih oleh isteri dengan bekerja atau melalui pemberian pihak keluarga dari kedua belah pihak. Sebagaimana yang diungkapkan oleh salah satu narapidana (ZA selaku Informan VI) mengatakan:

"Keberadaan saya disini memang membuat saya tidak mampu memberikan nafkah dari apa yang saya hasilkan sebagaimana biasanya saya memenuhi kewajiban nafkah saat menjalani hukuman dan memiliki pekerjaan sebagai guru honorer. Sehingga isteri saya memilih untuk tinggal di kediaman orangtuanya. Namun kini dalam hal pemberian nafkah keluarga, saya hanya mendapat bantuan dari orang tua dan karib kerabat saya melalui transferan uang, sehingga ketika ada kiriman yang dirasa cukup besar, saya berikan kepada isteri saya, disamping itu alhamdulillah isteri saya tidak pernah menuntut hak-hak nya (nafkah) selama saya berada disini melainkan sentiasa memberikan support/semangat untuk menjadi insan yang lebih baik lagi demi keutuhan rumah tangga kita, kata beliau". (Wawancara, 17 Oktober 2017)

Dari keterangan yang diberikan oleh Informan VI, hemat Penulis bahwa kewajiban nafkah tetap terlaksana namun dalam kualitas yang kurang mencukupi. Hal ini disebabkan oleh Informan VI yang sebelumnya memiliki pekerjaan sebagai guru honorer di sebuah Madrasah Tsanawiyah di salah satu Kabupaten Tanah Datar, dan setelah menjalani masa pidananya tidak lagi mendapatkan penghasilan dari profesinya. Sebagaimana ungkapan Informan VI di atas, dengan adanya kiriman dari orangtua maupun kerabat ketika mengunjungi tersebut Informan memilih untuk memberikannya kepada isteri guna pemenuhan kebutuhannya.

Keterangan yang sama dikemukakan oleh Informan XII yang juga mendapatkan kiriman dari kerabat memilih untuk memberikan kepada isteri ketika berkunjung. Sebagaimana keterangan berikut:

"Dari jumlah yang diberikan oleh teman, atau sanak saudara saya ketika membesuk, sebahagian besar saya berikan kepada isteri untuk keperluan dapur dan uang jajan anak saya. Meskipun terkadang isteri saya sering menolak pemberian saya dengan alasan mengkhawatirkan kebutuhan saya selama di dalam penjara ini, tapi saya tetap 
memohon untuk dipergunakan saja, meskipun dengan nominal yang tidak banyak. Agar ringan hati dan fikiran saya". (Wawancara, 27 Desember 2017)

Informan $X$ yang memiliki pekerjaan sebelumnya sebagai Supir Travel di sebuah P.O Transportasi Antar Provinsi menyatakan bahwa dengan keadaannya saat ini, membuat isterinya berjualan di salah satu kantin SMP di Batusangkar, sebagaimana pernyataan beliau:

"Memang dulu ketika saya bekerja menjadi supir travel riau-sumbar, isteri saya mengurus rumah tangga dan anak-anak saja, namun kini isteri saya terpaksa berjualan di kantin SMP semenjak keberadaan saya di sini, terkadang keluarga saya pun ada memberi sedikit bantuan materi kepada isteri dan anakanak saya." (Wawancara, 27 Desember 2017).

Keadaan yang sama dilakukan oleh Informan XV yang juga tidak lagi memiliki penghasilan apapun saat sedang menjalani masa pidana, satusatunya bentuk pemenuhan kewajiban nafkah hanya dari kiriman atau pemberian orangtua/kerabat kepada Informan dan diberikan kembali kepada isteri.

Menurut Penulis, keadaan seorang suami yang tengah menyandang status narapidana merupakan suatu keadaan yang sangat sulit untuk diterima baik oleh narapidana itu sendiri maupun oleh keluarga (isteri), namun dengan adanya pemahaman serta kesadaran dari para suami sebagaimana hasil wawancara terhadap Informan VI, XII, X dan XV merupakan sebuah kesadaran serta pemahaman terhadap kewajiban yang sangat luar biasa. Tidak bisa dipungkiri, untuk menerima keadaan sebagai narapidana saja sudah merupakan momok menakutkan bagi siapa saja, karena jauh dari kata kebebasan, ditambah dengan status sebelum mereka berada di dalam (penjara) sebagai seorang suami yang memiliki berbagai tanggung jawab dan kewajiban yang harus dipenuhinya. Dengan demikian, bentuk pelaksanaan kewajiban nafkah oleh suami yang berstatus narapidana terhadap isteri pada kategori ini dapat dikatakan terlaksana namun kurang, meskipun Informan tidak memiliki penghasilan lagi, dan hanya bersandarkan kepada kiriman atau pemberian kerabat Informan tidak menganggap bahwa tanggung jawab yang seharusnya dijalankannya dapat dibiarkan begitu saja, pilihan Informan untuk memberi kembali pemberian tersebut kepada isteri merupakan suatu pemenuhan kewajiban nafkah yang Penulis pandang sebagai pertanggungjawaban yang luar biasa terhadap isteri sebagai suatu bentuk ketaatan seorang suami kepada perintah Allah SWT.

Sehingga dapat Penulis garis bawahi bahwa keadaan suami yang berstatus narapidana yang pada saat ini hanya bersandarkan kepada kiriman atau pemberian dari orangtua maupun kerabat dapat dikatakan sebagai bentuk pelaksanaan kewajiban nafkah lahir yang tetap terlaksana namun dalam kualitas yang kurang.

\section{Tidak Terlaksana}

Pengelompokkan pelaksanaan kewajiban nafkah lahir oleh suami yang berstatus narapidana dikatakan tidak terlaksana dengan memiliki standarisasi tidak terpenuhinya dan atau kecilnya potensi kemungkinan isteri mendapatkan nafkah dari suami, 
karena kebanyakan dari jawaban wawancara yang Penulis temukan bahwa banyaknya isteri yang mengambil alih kewajiban suami dalam pemberian nafkah, sehingga isterilah yang memenuhi seluruh kebutuhan sehari-hari anak dan suami selama berada dalam tahanan. Sebagaimana yang diungkapkan oleh salah satu narapidana (IL selaku Informan VII) menyatakan:

"Dalam hal pemberian nafkah yang sudah menjadi kewajiban, saya rasa tidak terpenuhi selayaknya seorang suami menafkahi isteri dan anak-anaknya, sebagaimana dulu gaji PNS saya sepenuhnya dikelola oleh isteri guna kebutuhan, melainkan kini hal itu berbalik, isteri yang menafkahi anak-anak bahkan memenuhi kebutuhan saya selama menjalani masa pemidanaan dirutan ini. Isteri saya menjadi guru PNS di kediaman Dalam seminggu, 2 sampai 3 kali isteri saya membesuk saya sekaligus membawakan makanan dan uang belanja untuk kebutuhan saya di dalam". (Wawancara, 17 Oktober 2017).

Penulis dapat memahami terhadap pelaksanaan kewajiban nafkah oleh suami yang berstatus narapidana (sebagaimana yang dikemukakan Informan VII), bahwa pelaksanaan kewajiban nafkahnya dapat dikatakan tidak terlaksana, dikarenakan tidak adanya bentuk pemenuhan apapun yang diupayakan oleh Informan yang dilatarbelakangi dengan dicabutnya status PNS dan tidak memiliki usaha sampingan yang bergerak baik saat Informan sebelum berstatus narapidana maupun sudah. Sehingga untuk pelaksanaan kewajiban nafkah sama sekali tidak terpenuhi melainkan segala bentuk kebutuhan suami selama berada di dalam rumah tahanan mutlak dipenuhi oleh isteri.

Keadaan yang hampir serupa Penulis temukan pada Informan II yang juga berprofesi sebagai Pegawai Negeri Sipil (PNS) sebelum berstatus narapidana, dan isteri dari Informan II juga merupakan seorang Pegawai Negeri Sipil (PNS), dengan adanya penghasilan tetap yang didapati oleh isteri menjadikan segala bentuk kebutuhan suami selama berada di dalam rumah tahanan di penuhi oleh isteri.

Kategori pelaksanaan kewajiban nafkah lahir oleh suami yang berstatus narapidana ini Penulis mengemukakan bahwa kategori ini merupakan bentuk pelaksanaan kewajiban yang tidak terlaksana sama sekali oleh seorang suami, terbukti dengan adanya pernyataan keadaan yang mana isterilah yang memenuhi segala kebutuhan yang seharusnya ditanggung oleh seorang kepala rumah tangga yakni seorang suami. Dialami oleh Informan II, VII, IV, XIV dan I.

Berdasarkan keteranganketerangan Informan, Penulis memahami bahwa terdapat berbagai bentuk pemenuhan yang dilakukan oleh narapidana terhadap kewajiban nafkah oleh seorang suami kepada isteri, di antaranya dengan adanya usaha sampingan yang menghasilkan baik pada saat narapidana sebelum menjalani masa pidana maupun pada saat sedang menjalani masa pidana, yang mana usaha tersebut dikelola atas wewenang suami (narapidana) sebagai salah satu bentuk pemenuhan kewajiban nafkah suami secara tidak 
langsung. Dan dengan adanya suatu bentuk pemberian atau kiriman dari keluraga atau kerabat narapidana yang diberikan kepada narapidana kemudian di berikan kembali kepada isteri pun sebagai pemenuhan kebutuhan keseharian isteri.

Berkaitan dengan kewajiban nafkah lahir dari suami yang berstatus narapidana yang menjadi hak dari seorang isteri, Penulis memahami dalam wawancara yang telah Penulis lakukan bahwa ada dua sikap yang dikedepankan oleh keluarga, Pertama, pihak keluarga dalam hal ini adalah isteri ada yang menyikapi dengan tidak mempersoalkan hal nafkah tersebut, dalam artian meskipun nafkah atas isteri adalah suatu kewajiban dari suami namun dikarenakan adanya penghalang kewajiban tersebut, para isteri bisa memaklumi dan memaafkan. Hal ini didasari karena para isteri narapidana yang secara formal pun ikut bekerja dan mendapatkan penghasilan sendiri. Selain hal tersebut, pemakluman dari para isteri dikarenakan mereka mempergunakan atau menjual harta benda pribadi dan atau harta benda bersama untuk pemenuhan kebutuhan hidup selama suami berada didalam rumah tahanan. (Wawancara, 18-19 November 2017)

Penulis juga mengkonfirmasi kepada pegawai terkait ada atau tidaknya kebijakan yang difasilitasi oleh pihak Rumah Tahanan terhadap pemenuhan nafkah lahir maupun batin yang mana pada dasar pemenuhan kewajiban-kewajiban ketika mereka menyandang status narapidana Rutan Batusangkar tidak sepenuhnya dapat diimplementasikan. Ada berbagai peraturan yang membatasi kebebasan mereka, diantaranya sulitnya untuk berkomunikasi atau berhubungan dengan dunia luar sebagaimana ketika ia hidup bebas bersama-sama dan berdampingan dengan orang lain secara langsung hingga kehilangan kemerdekaan, kehilangan hak milik dan kehilangan hak lainnya. Akan tetapi, hak-hak tersebut dapat diminimalisir dengan adanya pembinaan dan kebijakan atas hak-hak narapidana, hal ini langsung Penulis konfirmasi kepada Kepala Pel. Tahanan Rutan Batusangkar yang menjelaskan sebagai berikut:

"Didalam Rutan Narapidana diwajibkan untuk berkelakuan baik diantaranya dengan mengikuti seluruh kegiatan yang telah difasilitasi oleh pihak rutan, salah satunya adanya bimbingan kerja, seperti pertukangan kayu, las listerik, pembuatan batako, ternak kolam ikan lele, sulaman, pembuatan pipa rokok dari tempurung, dan pemenuhan hakhak bersifat batiniah dari pihak rutan seperti sholat berjamaah, adanya ceramah agama dari berbagai link yang telah dibentuk, belajar membaca tulis al-qur'an, sehingga upaya rutan untuk meminimalisir hilangnya hak dari narapidana dapat dirasakan. Dan diantara kebijakan-kebijakan Rumah Tahanan Negara Klas IIB Batusangkar dalam mendukung para Narapidana untuk berhubungan dengan keluarga yang sangat mengedepankan rasa kekeluargaan, diantaranya Pertama, Dengan mengadakan openhouse setiap 1 (satu) kali dalam sebulan, dan disaat perayaan hari-hari besar Nasional maupun Hari Besar Islam, yang mana pada kesempatan ini narapidana dapat bertemu dengan keluarga, serta keluarga pun dapat berkunjung dan diperbolehkan membawa bawaan (makanan, uang dan lain sebagainya yang sah lagi patut). Kedua, Waktu berkomunikasi dengan keluarga via telepon, pihak Rumah Tahanan Negara Klas II B Batusangkar menyediakan 4 (empat) buah ponsel genggam yang didapat dipakai oleh 
narapidana untuk berkomunikasi dengan keluarga dengan tarif yang telah ditentukan oleh pihak terkait". (Arlen Gumanti. S, 2017)

Kewajiban nafkah yang harus dipenuhi oleh seorang suami ketika menjalankan masa pidana Undangundang mengatur bagaimana suami tersebut masih memiliki potensi untuk dapat menjalankan kewajibannya sebagai seorang suami. Pasal 14 ayat (1) huruf (g) Undang-undang Nomor 12 Tahun 1995 Tentang Pemasyarakatan menyatakan bahwa narapidana berkah mendapat upah atau premi atas pekerjaan yang dilakukan. Hal ini pula langsung Penulis konfirmasi kepada pihak Rutan Batusangkar terkait dengan kebijakan mereka terhadap efektifitas pelaksanaan peraturan tersebut. Berikut jawaban yang dipaparkan oleh Bapak Arlen Gumanti. $S$ selaku kepala Pel. Tahanan:

"Ada satu kendala dari narapidana dalam pemenuhan nafkah materi yang berkaitan dengan kebijakan pihak Rumah Tahanan Negara (RUTAN) yakni dengan adanya pelatihan dan pembinaan yang tidak memiliki market/pasar guna pemasaran hasil kerja dari pelatihan yang disediakan oleh pihak rutan. Sehingga tidak adanya profit berupa nominal uang yang diperoleh melalui hasil kerja dari pelatihan dan atau pembinaan yang dilakukan oleh narapidana untuk pemenuhan nafkah bagi keluarganya (isteri dan anak). Namun, ada sebahagian dari para Narapidana yang masih tetap bisa memenuhi kewajiban memberikan nafkah keluarga meskipun hasil tidak seperti biasanya sebelum suami berstatus narapidana. Baik itu melalui kiriman orang tua maupun kerabat dari narapidana, adapula dari usaha yang ditinggalkan oleh narapidana yang dilanjutkan oleh karyawan dan atau keluarga narapidana tersebut. Lain halnya bagi narapidana yang tidak memiliki pekerjaan tetap sebelum ia berstatus narapidana, pemenuhan nafkah materi dirasa memang tidak terpenuhi olehnya". (Wawancara, 17 Oktober 2017)

Penulis berpendapat dari keterangan yang diperoleh dari Informan terkait pelaksanaannya terhadap kewajiban nafkah lahir memang sangat sulit untuk dibebankan kewajiban sebagaimana mestinya pada saat sebelum menyandang status narapidana, juga dengan kurangnya efektifitas peraturan yang ditindak lanjuti dengan kebijakan dari pihak Rumah Tahanan yang belum memiliki pasar guna pemasaran hasil kerja dari pelatihan dan pembinaan yang dilakukan oleh narapidana. Sehingga, pemenuhan kewajiban nafkah lahir yang tidak terpenuhi selama narapidana menjalani masa pemidanaannya menjadi suatu pemakluman yang harus diterima oleh isteri dan keluarga.

\section{PANDANGAN ISLAM TERHADAP KEWAJIBAN NAFKAH SUAMI NARAPIDANA: SEBUAH ANALISA TEORI QIRAAH MUBADALAH}

\section{Kewajiban Nafkah Tetap}

Keadaan seorang suami yang masih memiliki potensi serta upaya yang dilakukan olehnya untuk memenuhi kewajiban nafkahnya kepada isteri meskipun sedang menjalani masa pidana masih dapat dibebankan kwajiban nafkah padanya. Sebagaimana yang dilakukan oleh para Informan pada pengelompokan pelaksanaan kewajiban nafkah terlaksana, para Informan mampu mencukupi segala bentuk kebutuhan isteri 
sebagaimana mestinya, baik ketika sebelum suami menjalani masa pidana maupun sedang menjalani masa pidana, dengan adanya usaha yang tetap bergerak dan menghasilkan serta adanya pelimpahan wewenang terhadap pengelolaan usaha serta asetaset yang ada. Pada kelompok terlaksana ini, terdapat 6 (enam) narapidana yang penulis sebut dengan Informan III, Informan $\mathrm{V}$, Informan VIII, Informan IX, Informan XI dan Informan XIII yang memiliki berbagai bentuk usaha sampingan ketika sedang menekuni profesi sebelumnya. Hemat peneliti, terhadap kepada enam orang Informan ini dapat dikategorikan bahwa kewajiban nafkah oleh suami tetap terlaksana sebagaimana mestinya meskipun pemenuhannya secara tidak langsung.

Berdasarkan QS. al-Baqarah [2]: 233, menurut Sayyid Sabiq, bahwa yang dimaksud dengan nafkah adalah memenuhi kebutuhan makan tempat tinggal (dan kalau ia seorang yang kaya maka pembantu rumah tangga dan pengobatan isteri juga termasuk nafkah). Hal ini dikarenakan seroang perempuan yang menjadi isteri bagi seorang suami mempergunakan segala waktunya untuk kepentingan suaminya dan kepentingan rumah tangganya. Pendapat ini juga diperkokoh oleh QS. an-Nisa'[4]: 34 bahwa laki-laki merupakan pimpinan bagi perempuan. (Sabiq, 2012: 429) tidak hanya sampai disana, suami juga tidak boleh mengabaikan nafkah isterinya sebagaimana hadist "cukup berdosa orang yang menyia-nyiakan orang yang menjadi tanggungannya" yang di- riwayatkan oleh Abu Daud, Nasa'i dan al-Hakim. (Qaradhawi, 2000: 230)

Sebagaimana telah termaktub pula di dalam Pasal 34 ayat (1) Undang-undang Nomor 1 Tahun 1974 tentang Perkawinan yang menyatakan bahwa suami wajib melindungi isterinya dan memberikan segala sesuatu keperluan hidup berumah tangga sesuai dengan kemampuannya. Pasal tersebut mengandung perintah kepada suami secara badaniah wajib melindungi isteri dan memberi segala keperluan hidup secara lahiriah maupun batiniah, suami harus memenuhi kebutuhan isterinya. Senada dengan hal tersebut, KHI Pasal 80 ayat 4 dinyatakan bahwa sesuai dengan penghasilannya suami menanggung: a) nafkah, kiswah dan tempat kediaman bagi isteri; b) biaya rumah tangga, biaya perawatan dan biaya pengobatan bagi isteri dan anak; serta c) biaya pendidikan bagi anak.

Menurut penulis, pelaksanaan kewajiban nafkah lahir oleh mereka kategori ini bukanlah suatu alasan untuk diberikannya dispensasi karena masih adanya kesanggupan yang dilakukan oleh informan terhadap pemenuhan kebutuhan isteri sehari-hari. Islam pun mengedepankan konsep kesanggupan yang serupa, sehingga mereka masih memiliki kewajiban nafkah sebagaimana mestinya seorang suami berkewajiban menafkahi isterinya.

\section{Kewajiban Nafkah Gugur dan Menjadi Terhutang}

Nafkah adalah kewajiban suami yang harus dipikulnya terhadap isterinya. Setiap kewajiban agama itu 
merupakan beban hukum, sedangkan prinsip pembebanan hukum itu tergantung kemampuan subyek hukum (mukhalaf) untuk memikulnya, berdasarkan firman Allah dalam QS. alBaqarah [2]: 286.

Peneliti beranggapan dengan status suami yang berstatus sebagai narapidana yang tidak memiliki usaha semenjak menjalani masa pemidanaan, dan pemenuhan kebutuhan sehari-hari diambil alih oleh isteri dengan bekerja atau melalui pemberian kerabat dapat dikatakan tetap menjalankan kewajibannya sebagai seorang suami, namun dalam kapasitas yang kurang maksimal sebagaimana informan dengan pengelompokan kurang terlaksana dan tidak terlaksana, dikarenakan memang minimnya upaya yang dapat dilakukan oleh suami terhadap pelaksanaan nafkah lahir tersebut.

Begitu halnya dengan keikutsertaan isteri dalam memenuhi kebutuhan sehari-hari dengan bekerja, karena dalam kondisi tertentu adakalanya memang suami tak mampu untuk menunaikan kewajban nafkahnya (double bourden). Kalangan ulama Syafi'iyah mengatakan bahwa isteri harus bersabar atau meminta fasakh yang nantinya akan bermuara pada talak. Sebaliknya, kelompok Malikiyah mengatakan bahwa beban nafkah pindah pada sang isteri bila dia mampu. Untuk menjawab persoalan ini, dapat di runut dari pola dasar hubungan suami-isteri dalam membina rumah tangga, al-Qur'an mengajarkan satu pola dasar yaitu mu'asyarah bilma'ruf (pergaulan atau hubungan yang baik). Artinya, adanya fleksibelitas hak dan kewajiban antara suami isteri yang harus dikedepankan demi menjaga keutuhan rumah tangga yang berasaskan mitsaqan ghalidhza. (Kodir, 2019: 370)

Melirik kembali persoalan istri narapidana yang "berbeban ganda" dalam hal tersebut menunjukkan sebuah relasi yang lebih mengarah kepada substansi, konteks, dan sosial tentunya. Suami yang memiliki keterbatasan kemerdekaan atas apa-apa yang menjadi kewajibannya, maka dari itu konsep hak dan kewajiban menjadi fleksibel, saling mengerti, saling mengisi dan saling menguatkan dalam mengemban tugas dan amanah rumah tangga.

Sebagaimana pada Pasal 80 ayat (4) dan (5) Kompilasi Hukum Islam (KHI) yang dapat disimpulkan bahwa nafkah keluarga/isteri bagi suami yang berstatus narapidana, terdapat 2 (dua) alternatif dalam pemenuhannya, pertama, dianggap sebagai hutang yang harus ditanggung oleh seorang suami atas hak-hak isteri selama suami berstatus narapidana. Sebagaimana hakikat hutang, maka serta merta harus dibayarkan, namun pembebanan kewajiban nafkah suami yang berstatus narapidana kedalam kategori hutang ini dapat dirunut oleh ayat 280 surat alBaqarah yang menyatakan: “Dan jika (orang yang berhutang itu) dalam kesukaran, Maka berilah tangguh sampai dia berkelapangan. dan menyedekahkan (sebagian atau semua utang) itu, lebih baik bagimu, jika kamu Mengetahui."

Memang, hukum menafkahi isteri adalah wajib, namun mani' suami yang 
menyandang status sebagai narapidana dengan segala upaya yang memang tidak mampu untuk menunaikan nafkah, hal ini dijawab oleh kaidah fiqh "al-Masyaqqah tajlibut taisiir" kesulitan itu hakikatnya mendatangkan kemudahan. (Jazuli, 2006: 9) Penghukuman kewajiban nafkah menjadi gugur sampai suami memiliki kelapangan terhadap pemenuhan kewajibannya kembali. Merunut QS. atThalaq [65]: 7: "hendaklah orang yang mampu memberi nafkah menurut kemampuannya. Dan orang yang disempitkan rezekinya hendaklah memberi nafkah dari harta yang diberikan Allah kepadanya. Allah tidak memikulkan beban kepada seseorang melainkan sekedar apa yang Allah berikan kepadanya. Allah kelak akan memberikan kelapangan sesudah kesempitan." (Mardiah, 2018)

Keadaan suami yang tengah menyandang status sebagai seorang narapidana ini merupakan salah satu penghalang atau kesulitan yang dihadapi olehnya guna memenuhi kewajiban nafkah kepada isterinya. Maka dari itu, penulis beranggapan bahwa mereka yang pada kategori kurang terlaksana dan tidak terlaksana dalam pelaksanaan kewajiban nafkah lahir pada isterinya ini dibebankan hutang padanya yang suatu waktu harus ia lunasi. Berbeda halnya jika isteri menggugurkan kewajiban nafkah dari suami sebagaimana pernyataan dari pada isteri yang tidak keberatan dan tidak pernah menuntut keadaan suami. Karena mengedepankan prinsip antara suami dan istri harus saling menanggung dan menjamin. Dapat diartikan, antara suami dan isteri ada hubungan kemitraan dan kesejajaran.

\section{KESIMPULAN}

Pelaksanaan kewajiban nafkah oleh suami yang berstatus narapidana di Rumah Tahanan Negara Klas II B Batusangkar terdapat tiga tipologi, Pertama terlaksana, dengan alasan adanya bentuk upaya yang dilakukan oleh suami (narapidana) seperti adanya usaha yang masih bergerak dan menghasilkan yang dapat dipergunakan oleh isteri untuk memenuhi kebutuhan sehari-harinya. Kedua kurang terlaksana, hal ini didasari dengan masih adanya potensi dari suami (narapidana) untuk memberikan nafkah kepada isteri melalui pemberian kerabat meskipun kualitas dari terpenuhinya kebutuhan nafkah tidak secara optimal, dan ketiga tidak terlaksana, ketiadaan upaya apapun yang dilakukan oleh suami (narapidana) membuat isteri yang mencukupi segala kebutuhan sehari-hari anak dan suami selama menjalani masa pidana.

Kewajiban nafkah suami yang tengah menjalani masa pemidanaan ini tidaklah bertentangan dengan hukum Islam, meskipun disatu sisi tetap berstatus sebagai seorang kepala kelurga yang memiliki kewajiban yang harus ditunaikan. Islam memandang hal itu kepada dua penetapan hukum, pertama kewajiban nafkah tetap, yang merunut kepada keumuman QS. al-Baqarah [2]: 233 dan QS. at-Thalaq [65]: 7. Kedua kewajiban nafkah gugur dan menjadi hutang yang juga tidak menafikan dua ayat sebelumnya, namun mengedepankan relasi fleksibelitas suami isteri (kesalingan) dan kaidah fiqh "alMasyaqqah tajlibut taisiir" kesulitan itu hakikatnya mendatangkan kemudahan. Itu artinya, terciptanya sebuah relasi yang lebih mengarah kepada substansi, 
konteks, dan sosial. Suami yang memiliki keterbatasan kemerdekaan atas apa-apa yang menjadi kewajibannya, maka dari itu konsep hak dan kewajiban menjadi fleksibel, saling mengerti, saling mengisi dan saling menguatkan dalam mengemban tugas dan amanah rumah tangga.

\section{DAFTAR PUSTAKA}

Bahri, Syamsul. (2015). “Konsep Nafkah Dalam Hukum Islam (Conjugal Need Concept In Islamic Law)." Kanun Jurnal Ilmu Hukum XVII(No 66).

Departemen Agama Republik Indonesia. (t.th). Al-Qur'an dan Terjemah, Jakarta: Syamiil Qur'an

Departemen Pendidikan Nasional. (2008) Kamus Pusat Bahasa, Jakarta: Pusat Bahasa

Direktorat Jendral Pemasyarakatan Kementrian Hukum \& HAM. (2017). "Sistem Database Pemasyarakatan." Direktorat Jendral Pemasyarakatan Kementrian Hukum \& HAM.

Fathihnuddin, Muhammad. “Aplikasi Kewajiban Suami Terhadap Isteri dikalangan Jamaah Tabligh (Tinjauan atas penerapan hak dan kewajiban suami isteri)", Skripsi, UIN Syarif Hidayatullah Jakarta.

Hakim, Lukman. "Pemenuhan Nafkah Batin Isteri yang Terpidana dan Implikasinya Bagi Keharmonisan Keluarga (Studi Kasus Lapas Wanita, Sukun, Malang)", Skirpsi, Universitas Islam Negeri Maulana Malik Ibrahim Malang.
Hariadi, Milda. (2017). "Interpretasi Makna Makruf Dalam Pemberian Nafkah." Universitas Islam Negeri Ar-Raniry Darussalam.

Jazuli, H. A. (2006). Kaidah-Kaidah Fikih: Kaidah-Kaidah Hukum Islam Dalam Menyelesaikan Masalah Masalah Yang Praktis. Jakarta: Kencana.

Kania, Dede. (2014). “Pidana Penjara Dalam Pembaharuan Hukum Pidana Indonesia." Yustisia 3(No 2).

Kisyik, Abdul Hamid. (1995). Bimbingan Islam Untuk Mencapai Keluarga Sakinah. Bandung: al-Bayan.

Kodir, Faqihuddin Abdul. (2019). Qira'ah Mubadalah. Yogyakarta: IRCiSoD.

Mardiah, Eliza Vena. (2018). "Kewajiban Nafkah Bagi Suami Yang Di Penjara Terhadap Isteri Menurut Tokoh Muhammadiyah Dan Tokoh AlWashliyah (Studi Kasus Di Kecamatan Percut Sei Tuan Kabupaten Deli Serdang Sumatera Utara)." Universitas Islam Negeri Sumatera Utara Medan.

Mustofa, Muhamad Bisri. (2019). “Hukum Nafkah Terhadap Keluarga Pada Gerakan Dakwah Jama'ah Tabligh." Nizham. 7(1)

Ningsih, Yulia. (2011). “Eksistensi Kewajiban Nafkah Terhadap Isteri Bekerja (Studi Komparasi Hukum Islam dengan Pendekatan Pengusurataan Gender)". Skripsi, IAIN Batusangkar.

Qaradhawi, Yusuf. (2000). Halal \& Haram. edited by R. Press. Jakarta.

Sabiq, Sayyid. (2012). Fikih Sunnah. (Cet III). Jakarta: Cakrawala Publishing. 
30

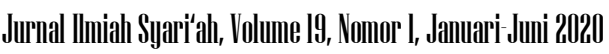

Subaidi. (2014). “Konsep Nafkah Menurut Hukum Perkawinan Islam." Isti'dal 1(2).

Susilawati, Esi. (2011). “Pelaksanaan Hak dan Kewajiban Suami Isteri (Studi Kasus di Nagari Pariangan Kabupaten Tanah Datar)". Skripsi IAIN Batusangkar.

Syarifuddin, Amir. (2006). Hukum Perkawinan Islam di Indonesia, Jakarta: Kencana

Tillahi, Mardha. (2012). “Dampak bagi Rumah Tangga isteri yang berprofesi sebagai TKI (Studi Kasus di Kecamatan Lima Kaum)". Skripsi IAIN Batusangkar.

\section{Wawancara}

Arlen Gumanti. S. (2017). Kepala Pel. Tahanan. wawancara, selasa, 17 Oktober

Betti Noon. (2018). Pegawai Rutan Rumah Tahanan Negara Kelas II Batusangkar. wawancara, april
Rini. (2018). Pegawai Rumah Tahanan Negara Klas II B Batusangkar, Wawancara, Senin 19 Februari, pukul 09.15 WIB.

Isteri-isteri Narapidana. (2017). Wawancara via telephone, Sabtu-Minggu, tanggal 18-19 November Pukul 14.00 \& 16.00 WIB.

Anonymous. (2017). Wawancara, di Rumah Tahanan Negara Klas II B Batusangkar, selasa tanggal 27 Desember, Pukul 14.10 WIB.

Anonymous. (2017) Wawancara, di Rumah Tahanan Negara Klas IIB Batusangkar, 17 Oktober, Pukul 09.00 - $12.30 \mathrm{WIB})$.

Anonymous. (2017). Wawancara, di Warung Sate Mak Etek Pincuran Tujuh, 31 Oktober 2017, pukul 11.30 WIB 